\title{
RACE, FAMILY STRUCTURE, AND WEALTH: THE EFFECT OF CHILDHOOD FAMILY ON ADULT ASSET OWNERSHIP
}

\author{
LISA A. KEISTER* \\ The Ohio State University
}

\begin{abstract}
Racial differences in wealth ownership are among the most extreme and persistent forms of stratification in the United States, but the factors that contribute to this inequality are unclear. One potentially important contributing factor is family background. It is a critical determinant of attainment, and both childhood family resources and family structure vary racially. This article reports that family size during childhood contributes significantly to racial differences in adult wealth. I find that siblings strain material and nonmaterial resources during childhood and decrease adult home ownership, stock ownership, and total assets. Having extended family in the home also decreases wealth for those from intact families, but an extended family minimizes the negative effect of divorce and separation and increases wealth in disrupted families. I also find that childhood family size and family structure are related to racial differences in adult wealth accumulation trajectories, allowing whites to begin accumulating high-yield assets earlier in life. The results provide insight into the role of family background in creating and maintaining inequality, particularly racial stratification in wealth ownership.
\end{abstract}

Racial inequality in wealth ownership is among the most extreme and persistent forms of stratification in the United States, and although there is abundant evidence of this, the processes that create these racial disparities continue to elude researchers (Conley 1999; Keister 2000a; Oliver and Shapiro 1995). Blacks and Hispanics, in particular, own considerably less wealth than do whites. In 1992, while median black income was about 60 percent of median white income, median net worth for blacks was only 8 percent of that for whites. In the same year, 25 percent of white families had zero or negative assets, but more than 60 percent of black families had no wealth (Oliver and Shapiro 1995). Longitudinal estimates suggest that between 1960 and 1995, whites were

* Direct all correspondence to: Lisa A. Keister, Department of Sociology, The Ohio State University, 300 Bricker Hall, 190 North Oval Mall, Columbus, OH 43210; e-mail: Keister.7@sociology.osu.edu.

Sociological Perspectives, Volume 47, Number 2, pages 161-187.

Copyright $(2004$ by Pacific Sociological Association. All rights reserved.

Send requests for permission to reprint to: Rights and Permissions, University of California Press, Journals Division, 2000 Center St., Ste. 303, Berkeley, CA 94704-1223.

ISSN: 0731-1214; online ISSN: 1533-8673 
twice as likely as minorities to have more wealth than income and nearly three times as likely to experience wealth mobility (Keister 2000b). Minorities are also underrepresented among the very wealthy. In 1995, 95 percent of those in the top 1 percent of wealth holders were white, while only 1 percent were black (Keister 2000b; Wolff 1998). The wealth position of other minorities has attracted less attention, but there is evidence that the wealth of whites also exceeds that of Hispanics and Asians (Campbell and Kaufman 2000; Wolff 1998).

Racial differences in family background are a potentially important cause of disparities in wealth ownership. However, research on wealth seldom considers family processes or family structure in its efforts to explain racial differences in wealth accumulation. There are clear racial differences in family structure. Notably, fertility, overall family size, and marital disruption are significantly greater among racial minorities than among whites (Horton and Thomas 1998; Ruggles 1994; Wilson 1987). There is also evidence that family structure during childhood shapes well-being and attainment both during childhood and in adulthood. Sibship size (number of siblings) and the occurrence of parental marital disruptions, for example, decrease educational and occupational attainment and increase the likelihood of poverty (McLanahan 1985; Sandefur and Wells 1999). In large families, resources are diluted, and children subsequently do not perform well in school and later life (Downey 1995b). Similarly, family disruptions interrupt education and learning, distract parents, dilute resources, and ultimately decrease children's attainment (Hanson and McLanahan 1998). Family size and disruptions are likely to affect adult wealth accumulation in similar ways, and research on wealth occasionally references this possibility. Yet efforts to explain racial inequality in wealth ownership focus almost exclusively on the role of income, investment behavior, and inheritance, without systematically examining the importance of family background (Blau and Graham 1990; Chiteji and Stafford 1999; Menchik and Jianakoplos 1997).

This article investigates the relationship between childhood family structure and racial differences in adult wealth ownership. I argue that family background is a critically important, albeit often overlooked, determinant of adult wealth. I propose that family size, the presence of extended family, and family disruption during childhood all contribute to adult wealth ownership and racial wealth inequality. Parental resources and human capital improve a child's adult wealth, while siblings and extended family dilute family resources and reduce wealth attainment. Similarly, I argue that family disruption during childhood reduces adult wealth, although extended family can minimize the negative impact of divorce and separation. Because family structure traits that are negatively related to wealth ownership occur more frequently in minority families, family structure is likely to be an important cause of racial differences in wealth ownership. I use the National Longitudinal Survey of Youth 1979 cohort (NLS-Y) to explore these ideas empirically. Results of standard regression analyses and sequence analyses of savings trajectories provide new insight into the role of family processes and family background in creating and maintaining inequality, particularly racial inequality in wealth ownership. 


\section{FAMILY BACKGROUND AND WEALTH}

\section{From Individual Traits to Family Background}

Previous research on wealth inequality focuses on the role of adult human capital and historic discrimination in shaping asset accumulation. The study of wealth has largely been the purview of economists, who emphasize the effect of education, current income, and work behavior (Danziger and Gottschalk 1993; Kennickell and Kwast 1997; Wolff 1998). Typical of human capital arguments, the theoretical basis for these claims is that individual traits improve decision making regarding saving, investment, and the acquisition of debt (Wolff 1995a, 1998). Research in this tradition does consider racial differences in wealth, but race is conceived of almost exclusively as fostering or impeding adult human capital (Wolff 1995b). Sociologists emphasize the importance of discrimination in housing and mortgage lending and differential appreciation of real estate (Oliver and Shapiro 1995). While individual attributes and discrimination are important, research on wealth has not moved beyond these to explore other processes that affect wealth inequality (Keister and Moller 2000).

Yet family background may be an important determinant of adult wealth and racial wealth inequality. Childhood financial family resources directly increase wealth in adulthood when parents make inter-vivos (while they are still living) transfers to their children and when they leave an inheritance. Similarly, nonmaterial resources such as parents' time and attention can increase adult wealth by improving human capital, social networks, and other important skills that translate into adult wealth. Because family background varies considerably by race, racial differences in wealth ownership may be attributable to family size and family structure.

\section{Family Size}

If financial resources in childhood increase adult wealth, it follows that processes that strain or dilute these resources will have the opposite effect on wealth. Family size, in particular, is likely to reduce the resources available to each family member and to diminish the attainment these resources can produce. In larger families, parents have fewer resources to invest in each child, and each child consequently fares worse both immediately and over time (Blake 1989). Research on educational attainment demonstrates that as family size increases, material resources, parental attention and intervention, and opportunities are reduced (Blake 1981; Hill and Stafford 1978; Stafford 1996). There are fewer material resources such as home quality, funds for education, space to study, and access to books and newspapers in larger families (Blake 1981; Teachman 1987). Children from larger families are also less likely to take dance and music lessons, to travel out of the United States, or to have other stimulating educational experiences (Blake 1989). Nonmaterial resources are similarly diluted in larger families. Parental involvement, encouragement, intervention, and opportunities to engage the world are all vital to well-being, and these are less available to children in larger families than to those in smaller families. As a result, people from large families perform worse in school and attain lower levels of education (Downey 1995b). 
For many of the same reasons that the dilution of material and nonmaterial resources in larger families reduces children's attainment in other areas such as education, family size is likely to reduce adult wealth accumulation (Keister 2003b). First, as family size increases, there will be fewer financial resources available during childhood. Financial resources improve educational opportunities, make educational resources such as books and other materials more readily available, provide support during college, and ease life transitions. Exposure to other educational experiences, access to newspapers and books, space to study, the presence of a computer in the home, music and dance lessons, foreign travel, and other experiences are also enhanced where financial resources are sufficient (Blake 1989; Downey 1995b). Financial resources make college more feasible and can prevent children from having to acquire debt as they complete higher education. Other life transitions may also be easier for children whose parents have relatively high resources. If their resources are adequate, parents may aid their children in purchasing a first home, in establishing a household after marriage, and in preparing for and taking care of children. To the extent to which these resources allow children to avoid debt and to begin accumulating assets, the starting point in wealth accumulation and the rate at which wealth is amassed across the life course will be lower in children from larger families.

Second, family size reduces inter-vivos transfers and inheritance (Keister 2003b). Any direct transfer of financial resources from parents to children has the potential to provide a base for savings that can grow even if additional savings are never added. In larger families, if there are any assets to be transferred, each child will receive a smaller portion. Receiving fewer resources from parents postpones the age at which wealth accumulation can begin and reduces overall wealth accumulation, because long-term compounding has less time to increase asset values. Children who receive fewer financial resources directly from their parents also own different assets and debts as adults. Inherited wealth is often used to make a down payment on a home, and a home is the most typical first investment for Americans, who tend to postpone investing in stocks, mutual funds, and bonds until they have purchased a home (Keister 2000b). Those who receive assets from their parents are therefore more likely to own both a home and other financial assets and, as a result, to accumulate wealth more quickly. Because even a relatively small inheritance can substantially increase the likelihood of home ownership, inheritance can create a stable base for saving across the life course. Processes that reduce or eliminate inheritance can have an equally negative effect on adult wealth.

Third, nonmaterial resources, including parents' time, energy, and encouragement, will be reduced in larger families (Blake 1981, 1989). In large families, parents have less time to help children with homework, to create educational opportunities, to provide encouragement, and to otherwise nurture and give positive reinforcement. Similarly, when there are more children competing in negative ways for attention (e.g., being rebellious, having problems at school), parents have less time to intervene. Children's opportunities to engage the world and to become involved in meaningful activities that feed into later life outcomes may also be fewer in large families. Similarly, educational experiences are more rare 
and the time parents have to reinforce the value of these experiences is less in large families (Keister 2003b). Researchers have shown that these nonmaterial resources are critical for children's development and can shape adult attainment. In their absence, attainment is likely to be reduced (e.g., Blake 1981).

Of course, there are some important nuances to this argument that need to be considered. Economies of scale, for example, in the provision of educational materials, might diminish the effect of siblings on adult outcomes. In families with many children, sharing educational tools such as books and computer resources might diminish the effect of family size. Likewise, it is possible for parents to provide educational experiences such as library trips for several children as inexpensively as for one child. Another caveat to this argument is that low-income parents might be more likely to help with child care if their opportunities for doing so are not high. Moreover, previous research has found evidence that siblings improve adult outcomes (Chetiji and Hamilton 2001; Guo and VanWey 1999; Henretta 1984). These factors may indeed diminish the effect of family size on adult wealth. However, the bulk of previous research on family background and adult attainment suggests that, on balance, it is likely that siblings reduce adult attainment. Consistent with this argument, I propose that family size will reduce adult wealth. That is, I expect that people from larger families will accumulate less wealth as adults. Moreover, because blacks and Hispanics tend to come from larger families, family size is likely to contribute to racial differences in wealth ownership. ${ }^{1}$

\section{Family Size and Poverty}

If the relationship between family size during childhood and adult wealth is largely a result of resource dilution, the effect of family size will be noticeable only when the family has sufficient resources to strain. More precisely, the negative effect of siblings is likely to be evident where financial resources exceed family needs because it is not until this point that resource dilution can take effect. At lower levels of family resources, there are insufficient resources to dilute, and the effect of additional siblings will be a strain but is unlikely to reduce adult wealth accumulation noticeably. The effect of family size in childhood on adult wealth is also likely to diminish at high levels of financial resources where additional strains are more easily absorbed financially. Thus, I expect that the effect of family size on adult wealth is likely to vary with the level of financial resources available in the childhood family. That is, the negative effect of family size on adult wealth will be particularly severe for those whose financial resources exceed their needs but will be diminished at high levels of financial resources. Because blacks and Hispanics are more likely to have grown up in poverty, this process is likely to account for an additional portion of racial differences in adult wealth.

Sibship size is also likely to be related to offspring attitudes toward consumption and to indirectly affect wealth accumulation even at constant levels of material and nonmaterial resources. By definition, people who save have a propensity to postpone consumption. In contrast, those with a low propensity to save exhibit other similar behaviors. For example, the strong positive relationship between educational attainment and wealth accumulation has been partially attributed to 
this preference for delayed consumption, and those who are upwardly mobile have been described as having a relatively strong preference for delayed gratification (Dynan 1993). Although the relationship is difficult to measure, couples with large numbers of children may have a preference for more immediate consumption (Friedman, Hechter, and Kanazawa 1994). In these families, children are less likely to learn to postpone consumption and to save, and their ability to accumulate wealth as adults will be lower as a result. Thus, it follows that family size will be associated with adult wealth even at constant levels of family resources.

\section{Family Disruption and Extended Family}

There is evidence that parents' separation or divorce decreases children's wellbeing both during childhood and into adulthood (Baydar 1988; Cooksey 1997; Demo and Acock 1988; McLanahan and Sandefur 1994). Experiencing divorce or separation decreases performance in school, reduces educational attainment (Downey 1995a; Houseknecht and Spanier 1980), and ultimately decreases occupational attainment and mobility (Biblarz and Raftery 1993). These children are less healthy both physically (Horwitz, White, and Howell-White 1996) and mentally (Cherlin, Chase-Lansdale, and McRae 1998) than those from intact families. There are also economic costs of experiencing marital dissolution. Divorce increases poverty rates (Duncan and Hoffman 1985; McLanahan and Sandefur 1994; Nestel, Mercier, and Shaw 1983) and decreases per capita income (Cherlin 1981; Mott and Moore 1978; Peterson 1996), labor force participation (Cherlin 1979), and the ratio of income-to-needs (Corcoran 1995), particularly for women (Holden and Smock 1991; Stirling 1989).

Because divorce and separation reduce school performance, educational attainment, occupational mobility, and health, there is likely to be an indirect effect of divorce and separation on wealth through these other processes. Divorce and separation are also likely to decrease direct transfers of assets from parents to children because financial resources will be spread across two households. If either parent does not remarry or marries a person with few independent financial resources, the resources available to that parent will be diluted. Resources may also be strained by settling financial disputes between parents, which can further reduce the resources that are devoted to raising children or transferred directly to them as financial assets. In addition, parental divorce and separation are likely to take an emotional toll on children that may decrease adult attainment, including wealth accumulation. Finally, family disruption may reduce the time parents have available to nurture children, to create stimulating educational experiences, or to intervene when they have problems (Mechanic and Hansell 1989). Thus, I anticipate that experiencing parents' divorce or separation as a child will be associated with lower adult wealth. Because black and Hispanic children are disproportionately affected by family disruption, this is likely to affect race-based wealth inequality.

Research on poverty suggests, however, that the negative effect of a family crisis such as divorce or separation may be lessened when the child is part of a larger family network (Marks 1991). In intact families, extended family members living in the home are likely to dilute resources and reduce children's long-term attainment. 
Additional family members reduce the resources that can be devoted to each child and have a long-term negative effect on the child's wealth. An important exception is that extended family may provide emotional support and contribute additional financial resources that lessen the negative long-term effect of divorce or separation. There is a tradition of qualitative research arguing that extended family can alleviate the effects of poverty for these reasons, and quantitative explorations of the effect have provided some support for this argument (Stack 1974). The effect of extended family on long-term wealth accumulation patterns has not been explored, but it is likely that extended family in the household affects asset accumulation in similar ways. Of course, extended family in nonintact families might also dilute resources. However, the positive effect of extended family is likely to outweigh the negative effect they might have on resources (Stack 1974). Likewise, extended family members in intact households may have a positive effect, but the effect is less noticeable because the need for intervention is lower. For these reasons, I anticipate that the presence of extended family in the household in intact families will decrease children's adult wealth ownership, but extended family will increase children's adult wealth if there is a divorce or separation in the family. Once again, these processes are likely to contribute to racial inequality in adult wealth as black and Hispanic children are more likely to spend time with extended family members in the home.

\section{RESEARCH DESIGN}

\section{Data}

I used the National Longitudinal Survey of Youth 1979 cohort to test these ideas. The NLS-Y is a nationally representative longitudinal survey that was administered eighteen times between 1979 and 1998 by the Bureau of Labor Statistics (BLS). The initial NLS-Y sample contained 12,686 individuals age fourteen to twenty-two in 1979 (i.e., born between 1957 and 1964). The sample had three components: a nationally representative sample; a supplemental sample of poor white, black, and Hispanic youth; and a supplemental sample of military members. Nearly 10,000 of the respondents were successfully interviewed through 1998. An extensive battery of wealth questions was added to the NLS-Y in 1985 when the youngest respondents were twenty years old. I used data from 1985 through 1998, when the respondents were between the ages of thirty-one and thirty-eight, to estimate pooled cross-section time series models of wealth ownership. I also drew on earlier surveys to gather information about the respondents' family backgrounds. Wealth questions were not asked in 1991, and the BLS began conducting the NLS-Y every other year starting in 1994 to reduce costs and respondent burden. Similarly, the BLS reduced the size of the supplemental samples to reduce expenses. As a result of these issues and because of missing values, wealth data are available for 3,053 respondents at eleven time points.

The NLS-Y is ideal for answering questions about family background and adult wealth because it combines broad longitudinal coverage of a large sample with detailed information about wealth holdings, family background, life transitions, and adult status. In each survey year beginning in 1985, respondents reported 
whether they owned a comprehensive list of assets and debts and the value of each asset or debt if they owned it. Other sources of survey data on wealth ownership include wealthier individuals, those who own most assets. The Survey of Consumer Finances, for example, is a cross-sectional data set (with panels in 1983, 1986, and 1989) that oversamples high income households to more accurately estimate wealth distribution (Kennickell, Starr-McCluer, and Sunden 1997; Wolff 1995a).

Because the NLS-Y does not oversample wealthy households, it may underestimate wealth concentration (Juster and Kuester 1991; Juster, Smith, and Stafford 1999). However, my objective is to estimate longitudinal patterns (e.g., the effect of family background on adult outcomes) rather than cross-sectional levels of inequality, and the NLS-Y data are consistent longitudinally with estimates from similar surveys and other data sources (Keister and Moller 2000). Moreover, the NLS-Y has been successfully used to estimate long-term family processes because it contains detailed information about family structure and processes during childhood, life transitions, and adult behaviors and status (Sandefur and Wells 1999). The Panel Study of Income Dynamics (PSID) is another longitudinal data set that contains both family background and adult wealth information (wealth information is included in 1984, 1989, 1994, 1999, and 2001). The PSID contains a less restricted age group than the NLS-Y and has been used to successfully model the relationship between family background and adult wealth (see, e.g., Conley 1999, 2001). After exploring both the NLS-Y and the PSID for these analyses, I opted to use the NLS-Y because it contains detailed information on the components of net assets. Of course, I could also have selected the PSID.

\section{Regression Models and Variables}

I used estimated generalized least squares (EGLS) regression to model net assets because the error terms were both heteroskedastic and correlated over time. ${ }^{2}$ I first modeled total assets as a function of race and the control variables. In the next three models, I added measures of childhood family structure to observe whether the family background measures affected race differences in wealth ownership. I then used logistic regression to model the likelihood of home ownership and stock ownership in adulthood to explore the mechanisms by which asset ownership varies by race. ${ }^{3}$ In the logistic regression models of home and stock ownership, I display only the first model (race and controls) and the last model (race, all family background indicators, and controls) to save space. ${ }^{4}$

In the first set of analyses, I modeled the dollar value of the net assets (standardized and logged) in the respondent's adult family, and I allowed this value to vary yearly between 1985 and $1998 .{ }^{5}$ Net assets is calculated as the value of total assets less the value of total liabilities. The financial assets included the value of stocks, bonds, and mutual funds; cash accounts such as checking accounts; trust accounts; Individual Retirement Accounts; 401K plans; and Certificates of Deposit. The real assets included the current market value of the primary residence or home; businesses, farms, and investment real estate; cars and other vehicles; and other possessions. The debts included mortgages on the primary residence; debt on businesses, 
farms, and investment real estate; debt on automobiles; and other debt. I used the CPI to adjust all asset and debt values to 2000 dollars. Ownership of a home or any stocks for each survey year between 1985 and 1998 was the dependent variable for the second set of models (see Table 5). Table 1 includes descriptive statistics for the dependent variable with separate estimates for white, black, and Hispanic respondents. Mean and median net assets in both 1985 and 1998 are significantly lower for blacks and Hispanics than for whites, and the estimates are consistent with other estimates of household wealth (Keister 2000a). I include separate estimates for 1985 and 1998 for illustrative purposes in the table, but I use the value for each survey year in the analyses. Likewise, I report the value of four assets in Table 1 for illustrative purposes, but I calculate total assets from the full list of assets and debts.

I included several measures to test ideas about childhood family structure and adult wealth. Table 2 reports means and standard deviations for the independent variables for all families. I include dummy indicators that a respondent was black

TABLE 1

Racial Differences in Wealth and Family Background

\begin{tabular}{|c|c|c|c|c|}
\hline & $\begin{array}{c}\text { All } \\
(N=3,053)\end{array}$ & $\begin{array}{l}\text { White } \\
(81 \%)\end{array}$ & $\begin{array}{l}\text { Black } \\
(13 \%)\end{array}$ & $\begin{array}{c}\text { Hispanic } \\
(6 \%)\end{array}$ \\
\hline \multicolumn{5}{|l|}{ Adult wealth ownership } \\
\hline \multicolumn{5}{|l|}{ Net assets, 1985} \\
\hline Mean & $\$ 24.7$ & $\$ 28.5$ & $\$ 8.4$ & $\$ 13.7$ \\
\hline Median & $\$ 5.1$ & $\$ 6.9$ & $\$ 0.8$ & $\$ 2.8$ \\
\hline \multicolumn{5}{|l|}{ Net assets, 1998} \\
\hline Mean & $\$ 115.3$ & $\$ 136.9$ & $\$ 27.9$ & $\$ 52.9$ \\
\hline Median & $\$ 39.1$ & $\$ 52.2$ & $\$ 3.8$ & $\$ 13.0$ \\
\hline \multicolumn{5}{|l|}{ Asset ownership, 1998 (\% owning) } \\
\hline Home & 60.0 & 66.3 & 30.8 & 46.1 \\
\hline Stocks and bonds & 21.3 & 24.4 & 8.7 & 11.1 \\
\hline Business & 12.7 & 14.7 & 3.8 & 7.1 \\
\hline Cash savings & 75.2 & 80.8 & 50.3 & 62.0 \\
\hline \multicolumn{5}{|l|}{ Childhood family environment } \\
\hline Number of siblings & $\begin{array}{c}2.92 \\
(2.25)\end{array}$ & $\begin{array}{c}2.69 \\
(2.02)\end{array}$ & $\begin{array}{c}3.81 \\
(2.71)\end{array}$ & $\begin{array}{c}4.03 \\
(3.11)\end{array}$ \\
\hline Above poverty line & $\begin{array}{l}.85 \\
(.35)\end{array}$ & $\begin{array}{c}.90 \\
(.27)\end{array}$ & $\begin{array}{l}.59 \\
(.49)\end{array}$ & $\begin{array}{l}.62 \\
(.48)\end{array}$ \\
\hline Parents separated or divorced $(\%)$ & $\begin{array}{c}.31 \\
(.13)\end{array}$ & $\begin{array}{c}.29 \\
(.11)\end{array}$ & $\begin{array}{l}.45 \\
(.22)\end{array}$ & $\begin{array}{c}.32 \\
(.14)\end{array}$ \\
\hline Extended family in home (\%) & $\begin{array}{l}.13 \\
(.34)\end{array}$ & $\begin{array}{l}.11 \\
(.31)\end{array}$ & $\begin{array}{l}.29 \\
(.46)\end{array}$ & $\begin{array}{l}.18 \\
(.36)\end{array}$ \\
\hline Mean family income in 1978 & $\begin{array}{c}\$ 38.14 \\
(\$ 40.07)\end{array}$ & $\begin{array}{c}\$ 41.41 \\
(\$ 41.86)\end{array}$ & $\begin{array}{c}\$ 24.40 \\
(\$ 27.01)\end{array}$ & $\begin{array}{c}\$ 25.03 \\
(\$ 28.93)\end{array}$ \\
\hline
\end{tabular}

Notes: Standard deviations are in parentheses. Net assets and family income are thousands of 2000 dollars (adjusted using the Consumer Price Index). I use values for each year between 1979 and 1998 in the analyses, but I include means for single years in this table for illustrative purposes. $N=3,053$. 
TABLE 2

Means and Standard Deviations for Independent Variables

\begin{tabular}{lc}
\hline & Mean $(S D)$ \\
\hline Childhood family structure & \\
Number of siblings & $2.92(2.25)$ \\
Above poverty line & $.85(.35)$ \\
Parents separated or divorced $(\%)$ & $.31(.13)$ \\
Extended family in home (\%) & $.13(.34)$ \\
Control variables & \\
Income in 1978 & $\$ 38.14(\$ 40.07)$ \\
Father had advanced degree & $.16(.36)$ \\
Mother had advanced degree & $.09(.29)$ \\
Income in 1998 & $\$ 62.39(\$ 51.08)$ \\
Ever had children & $.80(.40)$ \\
Number of children born & $1.69(1.34)$ \\
Married & $.53(.49)$ \\
Ever divorced & $.06(.23)$ \\
High school graduate & $.37(.48)$ \\
Some college & $.19(.39)$ \\
College graduate & $.11(.31)$ \\
Advanced degree & $.07(.27)$ \\
Age & $37.35(2.21)$ \\
Male & $.50(.50)$ \\
\hline
\end{tabular}

Notes: Income is mean household income in thousands of 2000 dollars (adjusted using the Consumer Price Index). I use values for each year between 1979 and 1998 in the analyses, but I include means for single years in this table to ease interpretation. $N=3,053$.

or Hispanic. ${ }^{6}$ Number of siblings is the total number of siblings ever born, reported in 1998. To indicate whether the family's income exceeded their needs, I included a dummy variable indicating whether the total household income and family size placed the family above the poverty line. I used the poverty indicator calculated by the BLS, a measure that is consistent with those calculated using the census and studied in previous research on income-to-needs ratios (Duncan and Rodgers 1991). To test ideas about the joint effect of childhood family size and family resources, I included an interaction term between number of siblings and the dummy variable indicating the family was above the poverty line. I also included the square of the interaction term to investigate the nonlinear relationship that I proposed among resources, siblings, and wealth. To test the effect of family disruption, I included a dummy variable indicating whether the respondent's parents were ever divorced or separated. ${ }^{7}$ I also included a dummy variable indicating whether the respondent's childhood family ever included extended family. ${ }^{8}$ Consistent with previous research, the estimates in Table 1 indicate that whites have fewer siblings than blacks and Hispanics on average, are less likely to have extended family living in the home, and are less likely to have experienced a family disruption during childhood. 
I controlled for various individual and family traits that are also likely to affect wealth. Family income is the logged value of total household income in 1978. To control for patterns that might be common to those with missing values on this key variable, I also included a dummy variable indicating that the respondent did not provide information about childhood family income (Sandefur and Wells 1999). I included separate dummy variables for father's education and mother's education that indicate whether the parents had completed college or more education. ${ }^{9}$ I controlled for financial resources in the family of origin by including measures of parents' net family income and education. Together, these measures provide an excellent proxy for their wealth, which is not available in the NLS-Y. Previous research suggests that these measures account for most of the variance in parental wealth, and my preliminary exploration using imputation, simulation, and synthetic wealth measures for the parents produced identical substantive outcomes.

To explore the possibility that the model estimates are biased because of an omitted variable, I imputed parents' wealth in three ways: I used Gary King's Amelia software to impute wealth from other very detailed information on family status in childhood; I used SAS Multiple Imputation to impute wealth; and I used the Survey of Consumer Finances from 1983 to assign wealth based on parents' and family characteristics. Next, I used each estimate separately and an average of the three estimates to respecify the models. Finally, I conducted a Langrange Multiplier test on each version of the model compared to the model without parents' wealth to test for the presence of omitted variable bias (Greene 2000:888). The results of the Langrange Multiplier test suggested that there was little if any bias from omitting the variable. The correlations ranged from .13 to .26. It is likely that I find these low correlations because I have included many other control variables for family conditions during childhood. In effect, I am controlling for all the correlates of wealth, and the direct effect of family wealth is thus minimal at best.

To capture the effects of region and immigration, I included (but did not display) indicators of region of birth, region of adult residence, and whether the respondent or her or his parents were born in the United States (three separate indicators). I also controlled for religious upbringing because religion affects many of the behaviors and processes that indirectly shape wealth, such as divorce, fertility, earnings, and education (Sherkat and Ellison 1999), and wealth itself (Keister 2003b).

Finally, I controlled for the human capital traits and family processes that previous research on wealth demonstrates can enhance or impede wealth accumulation. Income is total household income in the previous year (logged). ${ }^{10}$ I included income to control for the effect of adult financial resources on wealth. I also included a dummy variable indicating whether the respondent ever had children and a continuous indicator of the number of children ever born (lagged one year) to control for strains on adult financial resources. I included a dummy variable indicating whether the respondent was married (lagged one year) to measure the additive effect of combining assets in marriage. I also included a dummy variable indicating whether the respondent was ever divorced and an interaction term between having been divorced and having children to capture the strain of divorce on wealth. I included four dummy variables indicating educational attainment (high 
school degree, some college, bachelor's degree, or advanced degree) and a continuous indicator of age in all models to measure human capital. ${ }^{11}$ I controlled for gender with a dichotomous variable equal to one for males. I controlled for regional variation with dummy variables indicating residence in an urban area and residence in the north central, southern, or western United States. I controlled for race with dichotomous variables indicating the respondent was black or Hispanic in models that included people of all races. ${ }^{12}$

\section{Sequence Analysis}

Optimal matching, a method designed to identify common patterns or trajectories, is based on the notion that we can measure how similar two sequences are by determining how difficult it is to transform one into the other (Abbott and Hrycak 1990). Optimal matching has most commonly been used to identify and understand individual career patterns, but the method is equally suited for cataloging sequences in saving behavior. I used optimal matching to identify common patterns in the assets respondents owned over time. I included five assets with varying degrees of risk associated with them: savings accounts, checking accounts, a home, bonds, and stocks. If a person never owned an asset, the portfolio would be represented as 00000. If the person then opened a savings account but purchased no other assets, the portfolio would be represented as 10000 .

Optimal matching would indicate that it would take one substitution, substituting a one for a zero in the first column, to make the sequences identical. If each change (insertion, deletion, or substitution) "costs" the same, a simple count of the number of changes would indicate the complexity of the transformation; however, some transformations are inherently more difficult than others. Underlying this strategy is the notion that ownership of relatively high-risk assets early in life can propel net worth forward in ways that more conservative investment strategies, or no investment at all, cannot. If each insertion, deletion, or substitution required to transform one sequence to another had the same costs associated with it, a count of the number of changes would be sufficient representation of the difficulty of the transformation. In reality, some transformations are more difficult than others.

Consistent with previous applications of the approach (Abbott 1995; Abbott and Hrycak 1990), I derived my costs from a transition matrix that depicts patterns of financial behavior that appeared among respondents. The transition matrix allowed me to assess the likelihood of any given transition and assign an appropriate cost for that move relative to others. The substitution costs I used reflect these rankings such that unlikely changes are "expensive" and easier changes are less costly. Thus transitions from owning only a savings account to individual stocks are more costly than are transitions from owning only a savings account to owning a savings account and a checking account because the latter occur together more often in the complete matrix of options. The costs I used are similar in magnitude to those used in other applications of optimal matching (Abbott and Hrycak 1990). I experimented with alternative costs, including changing the magnitude of the substitution costs (e.g., to as high as 8) and the range of costs. I discovered 
TABLE 3

Substitution Costs for Optimal Matching

\begin{tabular}{lccccc}
\hline & Savings & Checking & Home & Bonds & Stocks \\
\hline Savings & - & 2 & 2 & 2.5 & 3 \\
Checking & & & 2 & 2.5 & 3 \\
Home & & & 2 & 3 \\
Bonds & & & & - \\
Stocks & & & & - \\
\hline
\end{tabular}

that even significant changes in the cost matrix produced only minor changes in the patterns the emerged. The substitution costs I used are given in Table 3.

Using this strategy, I identified three dominant patterns in asset ownership over the life course. Many respondents remained permanently asset poor: they never owned an asset and always had a portfolio labeled 00000. A traditional sequence, and one that emerged as quite common, is a sequence that involves a traditional wealth accumulation path. Those who followed this sequence typically acquired a checking or savings account (or both) during late adolescence, eventually bought a home as their first major investment, and may have eventually invested in stocks and bonds. The third common sequence that emerged was an early transition to financial asset ownership. Those who followed this type of pattern bought financial assets, stocks and bonds, early in life. Most of these people also had checking and savings accounts, and some eventually owned homes as well, but the dominant feature of this group was early entry into ownership of relatively high-risk assets. I discuss the distribution of people across these groups and the implications of each sequence for wealth accumulation below.

\section{RESULTS: FAMILY BACKGROUND AND ADULT WEALTH}

\section{Family size Decreases Wealth Inequality}

The findings in Table 4 support the hypothesis that family background is a critically important component of the explanation for racial wealth stratification. Table 4 presents Generalized Least Squares models of net assets from 1985 to 1998. Model 1 includes only the race indicators, and model 2 introduces number of siblings. Both models show that as number of siblings increases, adult wealth decreases. Adding measures of family size to the model also reduces the direct of effect of race and improves model fit slightly: the adjusted R-square increases from .11 to .18 , and Cox tests indicate that the change in the coefficient is significantly different from zero. This supports the argument that sibship size reduces adult wealth by diluting financial resources and the benefits associated with those resources. Ideally, the model would also control the amount of time parents spent with their children or other indicators of nonmaterial support. Unfortunately, details of this sort are not available in the NLS. This shortcoming aside, the findings in Table 4 suggest that to the extent to which blacks and Hispanics come from larger families, they will accumulate less wealth. 
TABLE 4

EGLS Parameter Estimates: Total Adult Family Net Assets, 1985-1998

\begin{tabular}{|c|c|c|c|c|}
\hline & Model 1 & Model 2 & Model 3 & Model 4 \\
\hline Black & $\begin{array}{c}-36.04^{* * *} \\
(3.15)\end{array}$ & $\begin{array}{c}-31.77^{* * *} \\
(3.19)\end{array}$ & $\begin{array}{c}-31.59^{* * *} \\
(3.27)\end{array}$ & $\begin{array}{c}-29.07^{* * *} \\
(3.29)\end{array}$ \\
\hline Hispanic & $\begin{array}{c}-30.90^{* * *} \\
(4.27)\end{array}$ & $\begin{array}{c}-25.91^{* * *} \\
(4.29)\end{array}$ & $\begin{array}{c}-24.43^{* * *} \\
(4.35)\end{array}$ & $\begin{array}{c}-22.64^{* * *} \\
(4.35)\end{array}$ \\
\hline \multicolumn{5}{|l|}{ Childhood family structure } \\
\hline Number of siblings & - & $\begin{array}{c}-3.76^{* * *} \\
(0.45)\end{array}$ & $\begin{array}{c}-2.10^{* * *} \\
(0.90)\end{array}$ & $\begin{array}{c}-2.10^{* * *} \\
(0.90)\end{array}$ \\
\hline Above poverty line & - & - & $\begin{array}{l}17.54^{* * *} \\
(5.21)\end{array}$ & $\begin{array}{l}16.64^{* * *} \\
(5.23)\end{array}$ \\
\hline Above poverty * number siblings & - & - & $\begin{array}{c}-6.76^{\star * *} \\
(1.59)\end{array}$ & $\begin{array}{c}-6.76^{\star \star \star} \\
(1.59)\end{array}$ \\
\hline$\left(\right.$ Above poverty ${ }^{*}$ number siblings) ${ }^{2}$ & - & - & $\begin{array}{l}0.57^{* * *} \\
(0.15)\end{array}$ & $\begin{array}{l}0.58^{* * *} \\
(0.15)\end{array}$ \\
\hline Parents separated or divorced & - & - & - & $\begin{array}{c}-16.75^{* * *} \\
(4.56)\end{array}$ \\
\hline Extended family in home & - & - & - & $\begin{array}{c}-41.94^{* * *} \\
(9.91)\end{array}$ \\
\hline Extended family * parents separated & - & - & - & $\begin{array}{l}43.33^{* * *} \\
(10.29)\end{array}$ \\
\hline \multicolumn{5}{|l|}{ Controls: childhood measures } \\
\hline Family income in 1978 (log) & $\begin{array}{c}0.31 \\
(0.27)\end{array}$ & $\begin{array}{c}0.22 \\
(0.27)\end{array}$ & $\begin{array}{c}0.16 \\
(0.28)\end{array}$ & $\begin{array}{c}0.97 \\
(0.39)\end{array}$ \\
\hline 1978 income not reported & $\begin{array}{c}3.43 \\
(3.34)\end{array}$ & $\begin{array}{c}2.38 \\
(3.34)\end{array}$ & $\begin{array}{c}1.98 \\
(3.37)\end{array}$ & $\begin{array}{c}1.82 \\
(3.36)\end{array}$ \\
\hline Father's education & $\begin{array}{l}17.17^{* * *} \\
(2.83)\end{array}$ & $\begin{array}{l}16.45^{* * *} \\
(2.83)\end{array}$ & $\begin{array}{l}16.07^{* * *} \\
(2.84)\end{array}$ & $\begin{array}{l}15.79^{* * *} \\
(2.84)\end{array}$ \\
\hline Mother's education & $\begin{array}{l}25.08^{\star * *} \\
(3.48)\end{array}$ & $\begin{array}{l}23.85^{\star * *} \\
(3.49)\end{array}$ & $\begin{array}{l}23.68^{* * *} \\
(3.49)\end{array}$ & $\begin{array}{l}23.32^{* * *} \\
(3.49)\end{array}$ \\
\hline
\end{tabular}

Controls: adult measures

Income (log)

Ever had children

$\begin{array}{lccc}0.10^{* * *} & 0.10^{* * *} & 0.10^{* * *} & 0.10^{* * *} \\ (0.01) & (0.01) & (0.01) & (0.01)\end{array}$

$\begin{array}{cccc}(0.01) & (0.01) & (0.01) & (0.01) \\ -1.93 & -1.83 & -1.66 & -1.47\end{array}$

Number of children born

$(2.68)$

$-1.66$

$-1.47$

$-0.95$

$(2.68)$

$(2.68)$

Married

$(1.04)$

$-0.05$

(2.68)

$-0.13$

$35.69^{* * *}$

(1.04)

$-0.02$

(1.05)

(2.13)

$35.47^{* * *}$

$35.10^{* * *}$

Ever divorced

$-5.65$

(2.13)

$35.33^{* * *}$

(2.13)

$(5.67)$

$-5.35$

(2.13)

$-5.07$

$-2.52^{*}$

(5.66)

$-5.24$

(5.66)

Divorced * ever had children

(1.30)

$-2.51^{*}$

(5.66)

$-2.43^{*}$

High school graduate

0.48

(1.30)

(1.30)

(1.30)

(2.73)

(2.73)

1.97

1.58

(2.75) 
TABLE 4 (Continued)

\begin{tabular}{lcccc}
\hline & Model 1 & Model 2 & Model 3 & Model 4 \\
\hline Controls: adult measures (continued) & & & & \\
Some college & $17.06^{* * *}$ & $17.47^{* * *}$ & $17.33^{* * *}$ & $17.22^{* * *}$ \\
College graduate & $(3.12)$ & $(3.11)$ & $(3.13)$ & $(3.13)$ \\
& $34.07^{* * *}$ & $33.70^{* * *}$ & $33.59^{* * *}$ & $33.23^{* * *}$ \\
Advanced degree & $(3.58)$ & $(3.57)$ & $(3.58)$ & $(3.59)$ \\
& $30.80^{* * *}$ & $29.88^{* * *}$ & $29.45^{* * *}$ & $29.31^{* * *}$ \\
Age & $(3.99)$ & $(3.99)$ & $(3.99)$ & $(3.99)$ \\
& 7.03 & 7.02 & 7.03 & 7.03 \\
Male & $(0.22)$ & $(0.22)$ & $(0.22)$ & $(0.22)$ \\
& 3.21 & 3.04 & 2.93 & 2.95 \\
Adjusted $R^{2}$ & $(1.87)$ & $(1.86)$ & $(1.86)$ & $(1.86)$ \\
$N$ & 0.11 & 0.18 & 0.22 & 0.25 \\
& 3,053 & 3,053 & 3,053 & 3,053 \\
\hline
\end{tabular}

Notes: Standard errors are in parentheses. Equations are pooled cross-section time series Generalized Least Squares estimates, dependent variable is net assets (in thousands) in $t$, and independent variables are measured in $t-1$. Included in the models (but not displayed) are measures of childhood religious affiliation and church attendance, region and country of birth, immigrant status, and adult region of residence in the United States. ${ }^{*} p<.05 ;{ }^{* *} p<.01 ;{ }^{* * *} p<.001$.

The race effect is also reduced by the degree to which family resources are sufficient to absorb additional siblings (again, model significance increases and Cox tests indicate that the change in the coefficient is significantly different from zero). To further explore the joint effect of childhood family size and resources on adult wealth, model 3 includes a dichotomous indicator of whether the family was above the poverty line, that is, whether the family's needs exceeded their income. The model offers strong support for the conditional impact of siblings on adult wealth. Being above the poverty line during childhood increases wealth, but the interaction between sibship size and being above the poverty line is negative. In other words, the negative effect of siblings on adult wealth is particularly strong for those whose families' income exceeded their needs. This finding supports the idea that siblings reduce adult wealth by diluting childhood resources because it is those who have sufficient resources who are more strongly affected by additional siblings. Those whose families did not have sufficient resources to be above the poverty line may have suffered at the addition of another child, but because their resources were already so limited, the increase in family size did not further dilute resources that would otherwise have increased the children's adult wealth accumulation.

At higher levels of family resources, however, the joint effect of resources and sibship size begins to decline. Model 3 also includes a squared interaction term, and the coefficient estimate for this term is positive and significantly greater than zero. At high levels of resources, the negative effect of siblings is still present, but it declines. One interpretation of this finding is that where family resources are greater, the family is better able to absorb additional siblings and the effect of 
sibship size on adult attainment is reduced. Where resources are greater, children have access to opportunities and connections even if they have a large number of siblings. Because these models also control for race and other predictors of adult wealth, these effects are net of these other effects. Yet because the incidence of poverty is greater among blacks and Hispanics than among whites, the effect of childhood poverty status does account for racial differences in adult wealth ownership (Corcoran 1995). Similarly, greater fertility rates among blacks and Hispanics imply that minorities will be more likely to suffer the negative effect of family size on adult wealth (Horton and Thomas 1998).

\section{Family Disruptions Shape Racial Wealth Inequality}

Status attainment literature linking family structure to adult outcomes demonstrates extensively and consistently that being raised in a nonintact family reduces educational advancement, occupational attainment, and a host of other measures of adult well-being (Corcoran 1995). Yet there is currently no research linking family disruption during childhood with adult wealth accumulation. To investigate whether coming from a nonintact family impedes wealth accumulation, model 4 adds an indicator of whether the respondent's parents were ever divorced or separated. The results demonstrate that family disruption reduces adult wealth accumulation and racial differences in adult wealth. The coefficient estimate is negative, it is significantly different from zero, and its magnitude is substantial. In preliminary analyses, I explored controlling for various other indicators of family disruption, using previous literature on family structure as a guide. Other measures, including separate measures for divorce and separation, the number of separations, timing of the separation, whether the parents remarried, and how soon they remarried, did not improve model fit. For these reasons, I included only the dichotomous indicator that a family disruption occurred.

Model 4 also includes an indicator of whether members of the extended family ever lived in the home. The presence of extended family further reduces adult wealth, consistent with the argument that additional people in the household reduce access to material and nonmaterial resources. Yet the effect of extended family is reversed in nonintact families. The interaction between having extended family in the home and the indicator of parental marital disruption is positive. What is most striking is the degree to which model 4 demonstrates a reduced direct effect of race on wealth ownership. The family size and family structure variables are all quite strong and significant, and the direct effect of being black or Hispanic is reduced.

These results are largely consistent with previous research; however, they suggest relationships that are not evident in one set of previous work. Conley (1999) finds that number of siblings and years in a female-headed family do not affect adult wealth. Conley used the PSID to explore these relationships and reports a finding quite different from mine. Yet theoretical work on resource dilution (e.g., Downey 1995a, 1995b) and other empirical work on the effect of siblings and childhood family structure on adult wealth ownership (Keister 2003a) are consistent 
with the findings that I report. Theoretically, the effect of siblings is likely given the effect of larger families on the dilution of both material and nonmaterial resources in childhood. Similarly, Conley (1999) finds that ethnic differences disappear once education, income, and gender are controlled. Yet other researchconsistent with the findings presented here-finds that the race effect remains in the presence of these controls (Keister and Moller 2000). One possible explanation for these differences may be found in the complexities involved in using large longitudinal data sets. For instance, it is possible that nuances in model specification and estimation are responsible for these differences, and an important direction for future research would be to analyze the NLS and PSID simultaneously and to compare results across these data sets.

Another possible explanation for these differences is the absence in my models of a control for family wealth during childhood. If family wealth is an important predictor of adult wealth, net entirely of the other childhood determinants of family wealth, it is possible that my models are misspecified. Because the NLS does not contain wealth of parents, however, I am unable to include that control. Yet, as I explain in the discussion of my research methodology, extensive exploration suggested that there was little if any omitted variable bias in the models I report. Naturally, there is no way to be sure of this without adding information on parents' wealth to the NLS; thus this explanation remains possible. It is also possible that the findings I report are unique to early adult wealth accumulation. As the NLS sample ages, it will be important to continue to update this research to understand the effects of family background on outcomes throughout adulthood.

These findings are also robust in the presence of human capital and other controls. The effects of the control variables were consistent with previous research on wealth ownership. Having highly educated parents increases adult wealth. The indicators of father's and mother's education increase adult wealth in each model in Table 4. Consistent with research on status attainment (Corcoran 1995; Teachman 1987), this supports the argument that parents with higher educations have a greater ability and inclination to create educational opportunities and other opportunities to engage the environment. These opportunities translate into greater adult wealth both directly and indirectly through educational attainment and adult earnings. Each model in this table also includes controls for the direct effect of respondent's educational attainment and other indicators of individual attainment, and these are significant predictors of adult wealth. Given these controls, the effect of parents' education reflects the direct effect of these measures on children's adult wealth. Consistent with previous research on the importance of parents' education, mother's education is a stronger predictor of adult wealth than is father's education (Teachman 1987). Wald tests confirm that the coefficient estimates for mother's education are significantly greater than those for father's education (Greene 2000). Consistent with previous wealth research, adult income, education, and age all increase wealth. Similarly, marriage increases wealth, while divorce reduces it particularly when the couple had children. In each model, parental immigrant status, religious affiliation, and religious participation are all significant predictors of wealth (to conserve space, these are not displayed). Both indicators for having a mother and a father who were born outside the United 
TABLE 5

Logistic Parameter Estimates: Home and Stock Ownership, 1985-1998

\begin{tabular}{lcccccc}
\hline & \multicolumn{2}{c}{ Home Ownership } & & \multicolumn{2}{c}{ Stock Ownership } \\
\cline { 2 - 3 } & Model 1 & Model 2 & & Model 3 & Model 4 \\
\hline Black & $-1.07^{* * *}$ & $-0.95^{* * *}$ & & $-0.57^{* * *}$ & $-0.39^{* * *}$ \\
& $(0.04)$ & $(0.04)$ & & $(0.06)$ & $(0.06)$ \\
Hispanic & $-0.54^{* * *}$ & $-0.45^{* * *}$ & & $-0.66^{* * *}$ & $-0.52^{* * *}$ \\
& $(0.05)$ & $(0.05)$ & & $(0.08)$ & & $(0.08)$
\end{tabular}

Childhood family structure

Number of siblings

Above poverty line

Above poverty * number siblings

(Above poverty * number siblings) ${ }^{2}$

Parents separated or divorced

Extended family in home

Extended family * parents separated

$\begin{array}{lclc}- & -0.01^{* * *} & - & -0.09^{* * *} \\ - & (0.00) & & (0.02) \\ & 0.34^{* * *} & - & 0.25^{* * *} \\ & (0.02) & & (0.01) \\ - & -0.08^{* * *} & - & -0.08^{* * *} \\ & (0.02) & & (0.01) \\ - & 0.01^{* * *} & - & 0.01^{* * *} \\ & (0.00) & & (0.00) \\ - & -0.23^{* * *} & - & -0.36^{* * *} \\ & (0.05) & & (0.08) \\ - & -0.41^{* * *} & - & -0.80^{* * *} \\ & (0.12) & & (0.02) \\ - & 0.28^{* *} & - & 0.60^{* * *} \\ & (0.12) & & (0.02)\end{array}$

Controls: childhood measures

Family income in 1978 (log)

1978 income not reported

$\begin{array}{cccc}0.01^{* * *} & 0.01^{* * *} & 0.01^{* * *} & 0.03^{* * *} \\ (0.00) & (0.00) & (0.00) & (0.01) \\ 0.05 & 0.04 & 0.05 & 0.01 \\ (0.04) & (0.05) & (0.05) & (0.05) \\ 0.00 & 0.02 & 0.33^{* * *} & 0.30^{* * *} \\ (0.03) & (0.03) & (0.04) & (0.04) \\ 0.02 & 0.04 & 0.24^{* * *} & 0.21^{* * *} \\ (0.04) & (0.04) & (0.05) & (0.05)\end{array}$

Controls: adult measures

Income (log)

$0.01^{* * *} \quad 0.01^{* * *} \quad 0.02^{* * *} \quad 0.02^{* * *}$

Ever had children

Number of children born

(0.00)

$(0.00)$

$(0.00)$

$(0.00)$

$0.25^{* * *} \quad 0.25^{* * *} \quad-0.20^{* * *} \quad-0.21^{\text {*** }}$

$\begin{array}{llll}0.25 & (0.03) & (0.03) & (0.04)\end{array}$

Married

0.00

0.01

$-0.14^{* *}$

$-0.12^{* * *}$

$(0.01)$

$(0.01)$

$(0.02)$

(0.02)

$1.95^{\star * *} \quad 1.94^{* * *} \quad 0.61^{* * *} \quad 0.59^{* * *}$

Ever divorced

(0.03)

$(0.03)$

$(0.04)$

$(0.04)$

$-0.40^{* * *}$

$-0.38^{* * *}$

$-0.01$

$-0.03$

(0.07)

(0.07)

Divorced * ever had children

$-0.09^{* * *}$

(0.10)

$(0.10)$

(0.02)

$(0.02)$

$(0.02)$

$(0.02)$ 
TABLE 5 (Continued)

\begin{tabular}{|c|c|c|c|c|}
\hline & \multicolumn{2}{|c|}{ Home Ownership } & \multicolumn{2}{|c|}{ Stock Ownership } \\
\hline & Model 1 & Model 2 & Model 3 & Model 4 \\
\hline \multicolumn{5}{|c|}{ Controls: adult measures (continued) } \\
\hline High school graduate & $\begin{array}{l}0.41^{* * *} \\
(0.03)\end{array}$ & $\begin{array}{l}0.40^{* * *} \\
(0.03)\end{array}$ & $\begin{array}{l}0.30^{* * *} \\
(0.05)\end{array}$ & $\begin{array}{l}0.28^{* * *} \\
(0.05)\end{array}$ \\
\hline Some college & $\begin{array}{l}0.46^{* * *} \\
(0.04)\end{array}$ & $\begin{array}{l}0.44^{* * *} \\
(0.04)\end{array}$ & $\begin{array}{l}0.72^{* * *} \\
(0.06)\end{array}$ & $\begin{array}{l}0.69^{* * *} \\
(0.06)\end{array}$ \\
\hline College graduate & $\begin{array}{l}0.53^{* * *} \\
(0.04)\end{array}$ & $\begin{array}{l}0.51^{* * *} \\
(0.04)\end{array}$ & $\begin{array}{l}1.31^{* * *} \\
(0.06)\end{array}$ & $\begin{array}{l}1.27^{* * *} \\
(0.06)\end{array}$ \\
\hline Advanced degree & $\begin{array}{l}0.37^{* * *} \\
(0.05)\end{array}$ & $\begin{array}{l}0.33^{* * *} \\
(0.05)\end{array}$ & $\begin{array}{l}1.26^{* * *} \\
(0.06)\end{array}$ & $\begin{array}{l}1.21^{* * *} \\
(0.06)\end{array}$ \\
\hline Age & $\begin{array}{l}0.16^{* * *} \\
(0.00)\end{array}$ & $\begin{array}{l}0.16^{* * *} \\
(0.00)\end{array}$ & $\begin{array}{l}0.04^{* * *} \\
(0.00)\end{array}$ & $\begin{array}{l}0.04^{* * *} \\
(0.00)\end{array}$ \\
\hline Male & $\begin{array}{l}0.11^{* * *} \\
(0.02)\end{array}$ & $\begin{array}{l}0.12^{* * *} \\
(0.02)\end{array}$ & $\begin{array}{l}0.14^{* * *} \\
(0.03)\end{array}$ & $\begin{array}{l}0.14^{* * *} \\
(0.03)\end{array}$ \\
\hline-2 Log likelihood & $50,515.35$ & $50,655.73$ & $69,247.93$ & $69,358.76$ \\
\hline$N$ & 3,053 & 3,053 & 3,053 & 3,053 \\
\hline
\end{tabular}

Notes: Entries are estimates of $\beta$; standard errors are in parentheses. These are not odds ratios. Equations are pooled cross-section time series estimates, dependent variable is a dummy variable indicating home ownership or stock ownership in $t$, and independent variables are measured in $t$-1. Included in the models (but not displayed) are measures of childhood religious affiliation and church attendance, region and country of birth, immigrant status, and adult region of residence in the United States.

${ }^{*} p<.05 ;{ }^{* *} p<.01 ;{ }^{* * *} p<.001$.

States reduce wealth, a reflection of the wealth that immigrants in the sample brought from their previous homes. The effect of being raised Jewish is among the strongest predictors of adult wealth, consistent with literature that argues for a cultural transmission of asset accumulation tools reflected in religious upbringing (Keister 2003b; Sherkat and Ellison 1999).

\section{Race and Portfolio Behavior}

Family background might affect adult wealth through portfolio behavior, or the combinations of assets and debts that families own at a point in time. Those with greater wealth in adulthood tended to buy real assets such as a home and financial assets such as stocks. Racial differences in ownership of these assets may contribute to overall differences in asset levels among families. Table 5 presents models that explore the effect of race and family background on the likelihood of adult home and stock ownership in order to examine whether family structure mediates the relationship between race and the ownership of specific assets. Model 1 demonstrates the effect of race and the control variables on home ownership, and model 2 introduces the full model, including all family background measures. Consistent with the results presented in Table 4 , the direct effect of race is reduced 
considerably and model fit improves when the family background measures are introduced. The direction and significance of the family background measures are also consistent with those reported in Table 4 . These results document that childhood family size and family structure directly affect the likelihood of home ownership and account for at least part of the racial difference in home ownership rates.

Similarly, the ownership of financial assets, such as stocks, contributes to total adult wealth, and racial differences in the propensity to own financial assets appears to underlie racial wealth inequality. Models 3 and 4 in Table 5 explore the degree to which family background reduces the direct effect of race on the propensity to own stocks. Model 3 documents severe racial differences in stock ownership with no family background controls. Model 4 introduces all family background measures. Again, introduction of the family background variables reduces the effect of race and improves model fit. In this model, the direction of the family background variables are once again in the predicted direction and statistically significant.

\section{Race, Family, and Savings Trajectories}

Another way to identify the mechanisms underlying the relationship between family background and adult wealth is to explore the savings trajectories that people follow during their lives. Those with greater adult wealth tend to begin accumulating assets at an earlier age and tend to begin saving in higher-yield assets earlier. Saving early in life can disproportionately affect adult wealth because of compounding. Naturally, early saving in high-return financial instruments can have an even more noticeable impact. An important part of the financial repertoire that children learn, and that can be associated with the family's religious preferences, is a propensity to begin saving early or to save in particular ways. Table 6 includes descriptive statistics that emerge from optimal matching. Using optimal matching on savings in five common assets at various levels of risk (savings accounts, checking accounts, home ownership, bonds, and stocks), I identified three common financial trajectories. The first trajectory, permanently asset poor, includes those who never own any of the five assets. The second trajectory, traditional wealth accumulation path, includes all trajectories that reflect some ownership of these assets with a tendency to start by owning the low-risk assets (savings, checking) in early adulthood, moving to home ownership, and then perhaps buying riskier financial assets (stocks, bonds) later in life. The third trajectory, early transition to financial asset ownership, includes all trajectories that again involve some ownership of these assets but that involve relatively early transitions to the ownership of financial assets (stocks, bonds). ${ }^{13}$

The results presented in Table 6 indicate that 23 percent of the full sample remained permanently asset poor throughout their lives, while 44 percent followed the more traditional wealth accumulation path, and only 10 percent made an early transition to financial asset ownership. Not surprisingly, there are stark racial differences in the paths people followed. Considerably more blacks and Hispanics than whites remained asset poor into adulthood, while considerably 
TABLE 6

Percent of People Following Three Typical Trajectories by Race and Family Background

\begin{tabular}{lccc}
\hline & $\begin{array}{c}\text { Traditional } \\
\text { Wealth } \\
\text { Permanently } \\
\text { Asset Poor }\end{array}$ & $\begin{array}{c}\text { Early Transition } \\
\text { Path }\end{array}$ & $\begin{array}{c}\text { Financial } \\
\text { Asset } \\
\text { Ownership }\end{array}$ \\
\hline All & .23 & .44 & .10 \\
White & .16 & .66 & .21 \\
All & .28 & .49 & .15 \\
With more than 3 siblings & .45 & .38 & .10 \\
Who lived in poverty as a child & .18 & .41 & .13 \\
Whose parents were divorced & & & \\
Black & .28 & .32 & .02 \\
All & .35 & .15 & .00 \\
With more than 3 siblings & .50 & .18 & .00 \\
Who lived in poverty as a child & .33 & .28 & .01 \\
Whose parents were divorced & & & .08 \\
Hispanic & .24 & .33 & .03 \\
All & .32 & .18 & .01 \\
With more than 3 siblings & .48 & .25 & .01 \\
Who lived in poverty as a child & .29 & .30 & \\
Whose parents were divorced & & & \\
\hline
\end{tabular}

Notes: "Permanently asset poor" families had not begun to accumulate savings by 1998. Those following a "traditional path" typically started with few assets, bought a house, then began to invest in financial assets. Those who made an "early transition to financial asset ownership" invested in financial assets early in life, before accumulating many real assets such as a home.

more whites followed traditional savings trajectories. Even more striking is the finding that 21 percent of whites and fewer than 10 percent of either blacks or Hispanics made an early transition to financial asset ownership, a path that is quite likely to result in considerable savings. What is perhaps most remarkable is the effect that family structure has on the trajectories taken. For all races but particularly for nonwhites, those with three or more siblings were much more likely to remain asset poor and much less likely to follow either of the other two (more desirable) paths. Similarly, those who lived in poverty as children or whose parents were ever divorced or separated were much more likely to remain asset poor and much less likely to follow a traditional path or a path involving an early transition to financial asset ownership. Although these findings do not directly answer questions about mechanisms, they are strongly suggestive of the mechanism by which childhood family structure relates to adult wealth. Specifically, these results suggest that blacks and Hispanics begin saving more slowly if at all, that they are quite unlikely to follow paths that yield high savings, and that family size and family structure during childhood exacerbates these differences. ${ }^{14}$ These results suggest that the repertoire of skills and decision-making abilities learned in childhood may very well set a course of action that ultimately translates into high wealth. 


\section{CONCLUSION}

My primary objective has been to examine the relationship between family background and racial differences in adult wealth ownership. Previous research on wealth inequality emphasizes adult human capital effects (Kennickell 2000; Wolff 1995b). Yet a long tradition of research on status attainment suggests that childhood resources and family structure are likely to shape adult wealth both directly and through their effect on adult human capital (Corcoran 1995). I drew on research in this tradition to propose that because family background varies racially, racial differences in wealth accumulation may be a function of differences in childhood resources and family structure. My results support this proposition. I found that sibship size decreases adult wealth, consistent with the argument that additional siblings strain both material and nonmaterial resources. Sibship size was particularly salient for those whose families were above the poverty line, while the effect of additional siblings was reversed in families where resources far outpace needs. Some observers have downplayed the importance of sibship size (Guo and VanWey 1999). But the precise relationships that my results documented provide considerable support for the argument that siblings dilute resources. Moreover, given the strength of my findings, it is difficult to discount the importance of family size in shaping adult wealth ownership.

Previous research also demonstrates that family disruption during childhood impedes adult well-being (McLanahan and Sandefur 1994). Although the utility of extending this research to wealth outcomes is apparent, researchers had not yet explored the possible connection between parental divorce or separation and adult wealth. My analyses indicate that family disruption decreases adult wealth, but I also find that having extended family in the home can reduce the negative effects of the disruption. Not surprisingly, when extended family are present in intact families, they dilute resources and decrease children's wealth accumulation in much the same way that additional siblings do. Yet in nonintact families, extended family may reduce the magnitude of the crisis by providing emotional support, financial intervention, and a sense of stability that is otherwise missing. This finding speaks to the importance of research on wealth accumulation and inequality that extends beyond the individual to include processes in both the immediate and the extended family. It is important to note that even when these processes are controlled, the race dummy variables remain significant. This is probably because there are important processes that are impossible to control with these (or any existing data) that also contribute to racial differences in wealth ownership. Informal education regarding saving and investment, for example, might account for accumulation differences. Yet there is no reliable way to test this possibility with current data.

I also found evidence that family background may reduce the effect of race on wealth via portfolio behavior and savings trajectories. Blacks and Hispanics are less likely than whites to own homes and stocks, two critical assets. Introducing family background into the equation, however, reduced the direct effect of race and provided additional explanatory power. Similarly, results of sequence analyses provided support for the argument that the paths on which people save vary 
by race. I found that whites were much less likely than blacks or Hispanics to remain with little or no savings into adulthood and that whites were much more likely to begin buying homes and financial assets earlier in life. These small differences in sequencing can create important differences in overall wealth both in the early years and across the life cycle. Family size and family structure during childhood exacerbated these effects and may contribute to racial differences in these behaviors.

These results suggest that the extreme and persistent racial divide in wealth ownership is at least partially traceable to family processes during childhood. It is important to note that in emphasizing the relationship between family background and wealth ownership, I do not intend to reduce the complex process of wealth accumulation or wealth inequality to a single set of inputs. Other research clearly documents that wealth ownership is associated with a number of factors, including individual and family processes such as marital behavior, investment patterns, and union separation and aggregate processes such as demographic trends, market fluctuations, and policy shifts (Keister and Moller 2000). The results that I discuss in this article, however, highlight an important part of the picture that has been neglected previously. Understanding that family background is related in critical ways to adult wealth accumulation, net of its indirect effects on other demographic behaviors, casts light on the importance of family processes that shape the way people behave and, in this case, the way they accumulate assets. My results also identify the importance of longitudinal patterns of saving behavior in shaping a person's lifetime wealth ownership. The person who starts life without the knowledge or skills to save or the understanding of how to save starts at a distinct disadvantage. Likewise, understanding that family structure can facilitate this process suggests that providing incentives to change some behaviors could enhance efforts to increase equality.

Acknowledgments: I am grateful to Emily Click and Claire Yang for research assistance. I also gratefully acknowledge comments from participants at the Jerome Levy Economics Institute's Conference on Saving, Intergenerational Transfers, and the Distribution of Wealth. This research was supported by grants from the American Sociological Association and the College of Social and Behavioral Sciences at the Ohio State University.

\section{NOTES}

1. Because I explore differences in asset accumulation among whites, blacks, and Hispanics, I am really exploring racial and ethnic differences. I do not repeat the term "ethnic" throughout this article to simplify the text.

2. The White Test for heteroskedasticy was significant, and the Ordinary Durbin-Watson Test (D-W) for first-order autocorrelation was significantly different from two. Because the Ordinary D-W was significant, it was not necessary to use the General D-W for high orders of autocorrelation. Practically, I used the Yule-Walker method, also known as the two-step full transform method or Estimated Generalized Least Squares, in SAS Proc Autoreg to estimate the models (Judge et al. 1985). 
3. Models of other components of wealth suggest that similar patterns are present by race. I opted to present home and stock ownership because home ownership is among the most common forms of asset ownership and stock ownership is suggestive of investment behavior that has the potential to yield high returns.

4. With data that follow the same individuals over such a long period, it is common to have some missing data. The NLS-Y is admirable in that it has retained a large sample size. Of course, missing values are still a problem. To address this, I used multiple imputation separately for each major test variable and each control variable, and I found the same results. I opted to use the nonimputed data (using listwise deletion in the regression analyses) because it is most standard and easiest to interpret.

5. Net assets is skewed as wealth ownership is concentrated in the hands of a relatively small portion of the population. Adding a constant to this variable (to eliminate negative values) and logging it reduces the skew. I also explored how removing outliers affects the results and found that given the large sample size, the results are robust to the removal of outliers.

6. Whites are nonblack, non-Hispanic respondents. Omitting those who do not report that they are Caucasian and coding the race variables in other ways, including a category for other races, does not change the results in a substantively meaningful way.

7. Never-married single parents were included in the omitted category. Including these parents as a separate category or with the separated and divorced parents did not change the results substantively.

8. I did not measure this as the number of extended family in the home because preliminary investigation suggested that the mere presence of extended family was the most salient measure of this variable.

9. Including a measure of number of years of education for the parents was less informative than controlling for various levels of education completed. Because completion of less than a college education was not significantly related to adult wealth, I included only one dummy variable.

10. I experimented with using a number of measures of income, including permanent income, average cumulative income, family income decomposed into the incomes of individuals in the household, total income decomposed into earned income and asset income. Yet I find no substantive difference in the results. The measure I chose to include, current income, lagged one year does change over time with the dependent variable. I have chosen to include it because among the representations of income, it is the simplest to interpret.

11. Consistent with previous research on wealth ownership, a squared age term did not significantly affect wealth in preliminary analyses.

12. I did not control for inheritance because including inheritance on the right side of a regression equation predicting wealth may be equivalent to including the dependent variable on both sides of the equation. Moreover, preliminary analyses indicated that controlling for inheritance did not change the substance of the results.

13. Each trajectory that I have grouped under these names includes multiple paths that optimal matching identified as relatively similar. These are not the only trajectories that emerged, but they are the most common paths followed by those in the sample.

14. It is possible to conduct multivariate analyses with the paths as the dependent variable defined as either dichotomous or multinomial. I do not report them here to conserve space and because the results do not add substantially to the results that are evident in the simple descriptive statistics. 


\section{REFERENCES}

Abbott, Andrew. 1995. "Sequence Analysis: New Methods for Old Ideas." Annual Review of Sociology 21:93-113.

Abbott, Andrew and Alexandra Hrycak. 1990. "Measuring Resemblance in Sequence Data: An Optimal Matching Analysis of Musicians' Careers." American Journal of Sociology 96:144-85.

Angel, Ronald and Marta Tienda. 1982. "Determinants of Extended Household Structure: Cultural Pattern or Economic Need." American Journal of Sociology 87:1360-83.

Baydar, Nazli. 1988. "Effects of Parental Separation and Reentry into Union on the Emotional Well-Being of Children." Journal of Marriage and the Family 50:967-81.

Biblarz, Timothy J. and Adrian E. Raftery. 1993. “The Effects of Family Disruption on Social Mobility." American Sociological Review 58:97-109.

Blake, Judith. 1981. "Family Size and the Quality of Children." Demography 18:421-42.

-1989. Family Size and Achievement. Berkeley: University of California Press.

Blau, Francine D. and John W. Graham. 1990. "Black-White Differences in Wealth and Asset Composition." Quarterly Journal of Economics May:321-39.

Campbell, Lori A. and Robert L. Kaufman. 2000. "Racial Differences in Household Wealth: Beyond Black and White." Working Paper. American Sociological Association.

Cherlin, Andrew J. 1979. "Work Life and Marital Dissolution." Pp. 23-38 in Divorce and Marital Separation, edited by G. Levinger and O. C. Moles. New York: Basic Books . 1981. Marriage, Divorce, Remarriage. Cambridge, MA: Harvard University Press.

Cherlin, Andrew J., P. Lindsay Chase-Lansdale, and Christine McRae. 1998. "Effects of Parental Divorce on Mental Health throughout the Life Course." American Sociological Review 63:239-49.

Chiteji, Ngina S. and Darrick Hamilton. 2001. "Inter-Family Connections and Race Differences in Saving Behavior: Towards a New Direction in Research on Wealth Inequality." Working paper.

Chiteji, Ngina S. and Frank P. Stafford. 1999. "Portfolio Choices of Parents and Their Children as Young Adults: Asset Accumulation by African-American Families." American Economic Review 89:377-80.

Conley, Dalton. 1999. Being Black, Living in the Red: Race, Wealth and Social Policy in America. Berkeley: University of California Press.

—. 2001. "Decomposing the Black-White Wealth Gap: The Role of Parental Resources, Inheritance, and Investment Dynamics." Sociological Inquiry 71:39-66.

Cooksey, Elizabeth C. 1997. "Consequences of Young Mothers' Marital Histories for Children's Cognitive Development." Journal of Marriage and the Family 59:24561.

Corcoran, M. 1995. “Rags to Rags: Poverty and Mobility in the United States." Annual Review of Sociology 21:237-67.

Danziger, Sheldon H. and Peter Gottschalk. 1993. Uneven Tides: Rising Inequality in America. New York: Russell Sage Foundation.

Demo, David H. and Alan C. Acock. 1988. "The Impact of Divorce on Children." Journal of Marriage and the Family 50:619-48.

Downey, Douglas B. 1995a. “Understanding Academic Achievement among Children in Stephouseholds: The Role of Parental Resources, Sex of Stepparent, and Sex of Child." Social Forces 73:875-94.

- 1995b. “When Bigger Is Not Better: Family Size, Parental Resources, and Children's Educational Performance." American Sociological Review 60:746-61. 
Duncan, Greg J. and Soul D. Hoffman. 1985. “Economic Consequences of Marital Instability." Pp. 427-67 in Horizontal Equity, Uncertainty, and Economic Well-Being, edited by M. David and T. Smeeding. Chicago: University of Chicago Press.

Duncan, Greg J. and Willard Rodgers. 1991. "Has Children's Poverty Become More Persistent?" American Sociological Review 56:538-50.

Dynan, Karen E. 1993. "The Rate of Time Preference and Shocks to Wealth: Evidence from Panel Data." Board of Governors of the Federal Reserve System Working Paper Series, No. 134.

Eggebeen, David J. and Daniel T. Lichter. 1991. "Race, Family Structure, and Changing Poverty among American Children." American Sociological Review 56:801-17.

Friedman, Debra, Michael Hechter, and Satoshi Kanazawa. 1994. "A Theory of the Value of Children." Demography 31:375-401.

Greene, William. 2000. Econometric Analysis, 4th ed. New York: Macmillan.

Guo, Guang and Leah K. VanWey. 1999. “Sibship Size and Intellectual Development: Is the Relationship Causal?" American Sociological Review 64:169-87.

Hanson, Thomas L. and Sara S. McLanahan. 1998. "Windows on Divorce: Before and After." Social Science Research 27:329-49.

Henretta, John. 1984. "Parental Status and Child's Homeownership." American Sociological Review 49:131-40.

Hill, C. Russell and Frank P. Stafford. 1978. "Intergenerational Wealth Transfers and the Educational Decisions of Male Youth: An Alternative Interpretation." Quarterly Journal of Economics 92:515-20.

Holden, Karen C. and Pamela J. Smock. 1991. “The Economic Costs of Marital Dissolution: Why Do Women Bear a Disproportionate Cost?" Annual Review of Sociology 17:51-78.

Horton, Hayward Derrick and Melvin E. Thomas. 1998. "Race, Class, and Family Structure: Differences in Housing Values for Black and White Homeowners." Sociological Inquiry 68:114-36.

Horwitz, Allan V., Helene Raskin White, and Sandra Howell-White. 1996. “The Use of Multiple Outcomes in Stress Research: A Case Study of Gender Differences in Responses to Marital Dissolution." Journal of Health and Social Behavior 37:278-91.

Houseknecht, Sharon K. and Graham B. Spanier. 1980. "Marital Disruption and Higher Education among Women in the United States." Sociological Quarterly 21: 375-89.

Judge, George G., William E. Griffiths, R. Carter Hill, and Tsoung-Chao Lee. 1985. The Theory and Practice of Econometrics. $2 \mathrm{~d}$ ed. New York: Wiley.

Juster, Thomas F. and Kathleen A. Kuester. 1991. "Differences in the Measurement of Wealth, Wealth Inequality and Wealth Composition Obtained from Alternative U.S. Wealth Surveys." Review of Income and Wealth 37:33-62.

Juster, Thomas F., James P. Smith, and Frank Stafford. 1999. "The Measurement and Structure of Household Wealth." Labour Economics 6:253-75.

Keister, Lisa A. 2000a. "Race and Wealth Inequality: The Impact of Racial Differences in Asset Ownership on the Distribution of Household Wealth." Social Science Research 29:477-502. . 2000b. Wealth in America. New York: Cambridge University Press.

. 2003a. "Sharing the Wealth: The Impact of Siblings on Adult Wealth Ownership." Demography 40:521-42.

. 2003b. "Religion and Wealth: The Role of Religious Affiliation and Participation in Early Adult Asset Accumulation." Social Forces 82:173-205.

Keister, Lisa A. and Stephanie Moller. 2000. "Wealth Inequality in the United States." Annual Review of Sociology 26:63-81.

Kennickell, Arthur B. 2000. "An Examination of Changes in the Distribution of Wealth from 1989-1998: Evidence from the Survey of Consumer Finances." Federal Reserve Board Working Paper. 
Kennickell, Arthur B. and Myron L. Kwast. 1997. “Who Uses Electronic Banking? Results from the 1995 Survey of Consumer Finances." Unpublished manuscript.

Kennickell, Arthur B., Martha Starr-McCluer, and Annika E. Sunden. 1997. "Family Finances in the U.S.: Recent Evidence from the Survey of Consumer Finances." Federal Reserve Bulletin January:1-24.

Marks, Carole. 1991. "The Urban Underclass.” Annual Review of Sociology 17:445-66.

McLanahan, Sara S. 1985. "Family Structure and the Reproduction of Poverty." American Journal of Sociology 90:873-901.

McLanahan, Sara S. and Gary D. Sandefur. 1994. Growing Up with a Single Parent: What Hurts, What Helps. Cambridge, MA: Harvard University Press.

Mechanic, David and Stephen Hansell. 1989. “Divorce, Family Conflict, and Adolescents' Well-Being." Journal of Health and Social Behavior 30:105-16.

Menchik, Paul and Nancy Ammon Jianakoplos. 1997. "Black-White Wealth Inequality: Is Inheritance the Reason?" Economic Inquiry 35:428-42.

Mott, Frank L. and S. F. Moore. 1978. "The Causes and Consequences of Marital Breakdown: Dimensions of Change in American Society." Pp. 113-35 in Women, Work, and Family, edited by F. Mott and S. H. Sandell. Lexington, MA: Lexington Books.

Nestel, G., J. Mercier, and Lois Banfill Shaw. 1983. "Economic Consequences of Midlife Change in Marital Status." Pp. 113-35 in Unplanned Careers: The Working Lives of Middle-Aged Women, edited by L. B. Shaw. Lexington, MA: Lexington.

Oliver, Melvin O. and Thomas M. Shapiro. 1995. Black Wealth/White Wealth. New York: Routledge.

Peterson, Richard R. 1996. "A Re-Evaluation of the Economic Consequences of Divorce." American Sociological Review 61:528-36.

Roschelle, Anne R. 1997. No More Kin: Exploring Race, Class, and Gender in Family Networks. Thousand Oaks, CA: Sage.

Ruggles, Richard. 1994. "The Origins of African-American Family Structure." American Sociological Review 59:136-51.

Sandefur, Gary D. and Thomas Wells. 1999. “Does Family Structure Really Influence Educational Attainment?" Social Science Research 28:331-57.

Sherkat, Darren E. and Christopher G. Ellison. 1999. "Recent Developments and Current Controversies in the Sociology of Religion." Annual Review of Sociology 25:363-94.

Stack, Carol. 1974. All Our Kin: Strategies for Survival in a Black Community. New York: Harper and Row.

Stafford, Frank P. 1996. "Early Education of Children in Families and Schools." Pp. 219-46 in Household and Family Economics: Recent Economic Thought, edited by P. Menchik. Boston: Kluwer Academic.

Stirling, Kate. 1989. “Women Who Remain Divorced: The Long-Term Economic Consequences." Social Science Quarterly 70:549-61.

Teachman, Jay D. 1987. "Family Background, Educational Resources, and Educational Attainment." American Sociological Review 52:548-57.

Wilson, William J. 1987. The Truly Disadvantaged: The Inner City, the Underclass, and Public Policy. Chicago: University of Chicago Press.

Wolff, Edward N. 1995a. "The Rich Get Increasingly Richer: Latest Data on Household Wealth during the 1980s." Pp. 33-68 in Research in Politics and Society, vol. 5, edited by R. E. Ratcliff, M. L. Oliver, and T. M. Shapiro. Greenwich, CT: JAI Press. 1995b. Top Heavy: A Study of the Increasing Inequality of Wealth in America. New York: Twentieth Century Fund. - 1998. "Recent Trends in the Size Distribution of Household Wealth." Journal of Economic Perspectives 12:131-50. 